\title{
'Being in the market': the UK house-price bubble and the intended structure of individual pension investment portfolios
}

Gordon L Clark, Roberto Durán-Fernández, and Kendra Strauss, Centre for Employment, Work and Finance, Oxford University Centre for the Environment, South Parks Rd., Oxford OX1 3QY, United Kingdom

Abstract. It is widely observed that being in the market gives financial traders access to knowledge and information not available to remote traders. A truism of the geography of finance, it is also a perspective that can shed light on the interaction between market location, global financial movements, and personal welfare. In this paper, we develop an explanation of the premium attached to being in the market, drawing upon previous contributions on the relevance of tacit knowledge and the insights provided by behavioural finance with respect to time-space myopia. To illustrate our model of 4 types of behaviour, mixing together various combinations of time and space conceptions of market performance, we analyse the intended retirement investment portfolios of nearly 2400 participants in a defined contribution pension plan sponsored by a London-based investment bank. Having demonstrated the empirical significance of the UK house-price bubble, respondents' retirement investment portfolios are analysed focusing upon the relative significance of property in relation to a range of other investment instruments. It is shown that, amongst similarly located respondents, there was a range of investment strategies dependent, in part, upon respondents' age, household status, job classification, and income. These results allow us to distinguish between different types of behaviour even amongst well-placed respondents, providing evidence of the co-existence of sophisticated, naive, and opportunistic investors against the base-case of time-space myopic behaviour. Implications are drawn for conceptualising a rapprochement between the insights of the behavioural revolution for economic geography (and in particular, the geography of finance) relevant for public policy.

Keywords. Housing bubble, behaviour, financial markets, investment portfolios

JEL Codes. D8, G14, G23

Contact. gordon.clark@ouce.ox.ac.uk

Acknowledgements. This paper was made possible by a ESRC CASE DPhil award for Kendra Strauss' DPhil at Oxford University, the industry sponsor Mercer Human Resource Consulting, Divyesh Hindocha from Mercers, and the cooperation of an unnamed investment bank located in London. We would especially like to thank the trustee board of the pension plan of that investment company for their interest in the research and the findings of the survey. We benefited from comments and corrections on previous drafts of this paper by two anonymous referees, Ewald Engelen, Paul Langley, Amelia Sharman, Olga Thonissen, Neil Wrigley and participants in an Oxford seminar. None of the above should be held responsible for any errors or omissions. Views expressed herein do not reflect or bear upon the advice or policies of Mercer Human Resource Consulting. 


\section{Introduction}

The latest UK house-price bubble came to an end in 2007 with the on-set of the subprime credit crisis which morphed into the global financial crisis. Over the previous decade, owners saw their homes double or triple in price; debate raged over the extent to which the boom was an asset-price bubble like the tech-bubble of the late 1990s. For those convinced that the housing boom was a bubble subject to pathologies of over-confidence and irrational exuberance, the bubble had to burst (Shiller 2008). There remains, however, a long-standing shortfall in supply that marks the UK housing market as somewhat different from that of the US. In the UK, the limited supply of housing, the demand for single- and multi-family rental accommodation, and the nature of urban regeneration in major cities reflected structural imperfections in property markets as well as a regulatory regime that truncated market response to burgeoning demand, especially in southern England (Hamnett 2008). ${ }^{1}$

Recognising the supply problems, Nickell (2005) and his colleagues nonetheless held that "there has been no housing bubble whatever". The 'optimistic' long-term scenario for UK housing markets, emphasizing market stability and supply constraints underwritten by rising real incomes, held sway over pessimistic assessments (see PricewaterhouseCoopers 2006). Even Shiller (2007, pp. 6-7) was circumspect about the "possible reversal in coming years" of the house-price boom, suggesting that, for the US at least, "it may be hard to understand from past experience what to expect next, since the magnitude of the boom (was) unprecedented." As is now widely recognised, the 'boom' was a 'bubble' and the accelerating global financial disaster was actually closer to hand than many realised-witness the September 2007 crisis of confidence in the UK building society turned-bank Northern Rock (National Audit Office 2009).

It could be argued that a financial crisis was believed so unlikely that all market participants were caught up in the emotion driving UK and global housing markets (Christie et al. 2008). In this paper, however, it is demonstrated that the housing bubble could be seen in the pattern of UK housing prices compared to the paths of

\footnotetext{
1. Affordable housing in relation to real incomes was a crucial issue for the UK Government over the last phase of the house-price boom. See Hamnett and Whitelegg (2007) and the HM Government (2007) 'green paper' on supply and the prospects for affordable environmental sustainability.
} 
real income growth and stock market movements over the previous two decades. Drawing upon recent developments in economic geography, it is hypothesized that those best able to assess market patterns and make reasoned judgements distinguishing the bubble from a boom relied upon the tacit knowledge available to skilled and experienced financial market participants. Gertler $(2003,78)$ notes that tacit knowledge is produced through practice and "the relationship between tacit knowledge and context is a reflexive one, since tacit knowledge both defines, and is defined by, social context." Our proposition is that being in the London financial market and having the knowledge and experience to judge the relative risks of property with respect to other retirement investment instruments were crucial ingredients in managing the risks of planning for the future.

We begin by mapping the nature and scope of market behaviour, recognising the insights of the behavioural revolution with respect to the time-space myopia of many people (Clark 2010). In doing so, we provide a schematic model of market participants emphasizing the role that knowledge, experience, and skill may have in generating different investment strategies amongst those similarly located. Thereafter, we focus upon the London employees of a large multi-national investment bank who either directly or by default sought to diversify the risks associated with property in their retirement savings and investment portfolios. Whereas commentators debated whether or not the UK was in the grip of a speculative bubble through to the on-set of the global financial crisis, it would appear that a number of our respondents sought a 'safety-first' strategy before the public at large realised the high costs associated with property as a pension investment option. While our respondents may not have anticipated the depth and consequences of the looming crisis, their intended investment strategies were consistent with a sophisticated approach to retirement planning.

Empirically, we look at this issue from three related vantage points: first, the degree to which components of UK workers' income were correlated with the path of house prices and stock market prices over the past 20 years; second, the degree to which house prices could be said to have exhibited bubble-like characteristics; and, third, the degree to which the employees of a London-based international investment bank (XXXX) expressed a preference for property in their retirement portfolios. Given the 
claims made about the value of property as a desirable form of retirement investment leading up to the crash, it could be hypothesized that respondents had strong preferences for property in their investment portfolios. Testing for patterns of response, it was found that few respondents would have relied, in fact, upon property; respondents' age, income, and risk tolerance were significant factors in discriminating between similarly-placed individuals in terms of their commitment to property as a form of retirement investment. Those respondents that would have property at the core of their pension investment portfolios seemed to do so either because of limited options or because their lack of experience let the gamble run-on.

Our respondents were deeply embedded in the world of global finance wherein the vast majority indicated a "good" or "very good" understanding of property and managed investment funds (compare with research on the financial knowledge and understanding of "average" UK employees; see Clark, Knox and Strauss 2009). Important for the paper is the empirical demonstration of bubble-like characteristics in the pattern of UK house prices, providing a crucial reference point for understanding the sophistication or otherwise of our respondents. This finding is useful, as well, in making informed argument against those who held the UK housing market was caught-up in more profound problems such as the unsustainable lending practices of major financial institutions. Coming at the peak of the property bubble and before widespread appreciation of the enormous costs of the global financial crisis, our research shows that there were sophisticated investors attuned to market risks across the range of retirement investment instruments even if they may not have applied that judgement to their bank's retail and wholesale investment funds. ${ }^{2}$

\section{Taxonomy of Market Behaviour}

Without doubt, the most successful research programme in economics (and the social sciences more generally) over the past thirty years was premised upon the assumption of rational agents and, hence, market efficiency. This assumption allowed analysts to ignore 'less-than-rational' behaviour based on the argument that other market agents

$\%$ For reasons of confidentiality we are not able to identify the name or national-origin of the investment bank. Readers will be interested to learn that company XXXX was not, initially, as badly affected by the global credit crisis as some other institutions, and certainly did not face the predicament of Lehman Bros and other banks that were forced into mergers with other institutions or were unwritten by their 'home' governments in the form of large equity stakes. Like almost all banks, though, its current situation is problematic. 
take advantage of those not able to effectively recognise and respond to market signals. By this logic, arbitrage drives markets to efficiency. As a consequence, there is little in the efficient markets hypothesis that can help to explain the systematic coexistence of different types of more or less skilled market agents. If tacit knowledge were significant for market agents, it is axiomatic that this information would drive the formation of market prices; any premium on tacit knowledge would be discounted over the long-term by virtue of market pricing.

Rational expectations were difficult to 'prove' and attempts to estimate market prices based upon its arguments required ad hoc adjustments so as to approximate observed patterns (Arrow 1986). If the 'governing' principle of finance, there were attempts to introduce more nuanced conceptions of market behaviour including Simon's (1956) notion that people, more often than not, satisfice rather than maximise and that people find it difficult to process information on a timely basis because of innate cognitive limits. As evidence accumulated demonstrating the existence of cognitive biases and anomalies, it also became apparent that financial markets exhibit systematic patterns of performance at odds with theoretical expectations (Shleifer 2000). The behavioural revolution gained traction because of the availability of large databases and the perceived commercial advantages of anticipating market behaviour (see Shiller 2000).

The core empirical finding of the behavioural revolution led by Tversky and Kahneman (1979) amongst others was that people are doubly myopic: people tend to be short-term oriented and they tend to rely upon the immediate environment for clues about responding to unanticipated events. This finding has been produced many times, often relying upon university students as respondents and the shared protocols governing experiments and testing procedures (Baron 2008). How and why this is the case is contentious. Some analysts invoke biological-cum-environmental determinism while others focus upon customary habits of mind and the costs of conscious deliberation (Kahneman 2003; Gabaix et al. 2006). Comparing university students with financial decision-makers that have significant roles and responsibilities, we also found strong evidence of myopia (Clark et al. 2006). But we also found for skilled and experienced respondents (as opposed to neophytes) that sophisticated decision-making techniques combined with context-specific knowledge can make a difference to solving financial problems (Clark et al. 2007). 
It can be shown that there is a range of behaviour in financial markets such that tacit knowledge when combined with the requisite skills can give some market agents leverage not available to other market agents. This does not mean that some agents are rational whereas others are not, nor does it mean necessarily that the co-existence of different types of market agents is not sustainable over the long-term. For Kahneman and Tversky, rationality is a human trait - the debate over whether humans are rational or not, which has bedevilled the social sciences for many years, is not at issue. Rather, domains that are subject to risk and uncertainty demand a level of sophistication that goes beyond basic levels of competency, learning-by-doing, and learning-by-interacting (Gertler 2003). For Kahneman and Tversky, the environment or context of behaviour matters a great deal for the effective performance of human rationality.

To illustrate this argument, Figure 1 provides a schematic of the possible scope of human behaviour in the context of risk and uncertainty. It is anchored by reference to 'myopia' in the upper left-hand box wherein people are transfixed by recent events that happen in their immediate activity space. To be myopic is to be parochial: to lack foresight and conceptual insight about the temporal pattern of market activity and the interaction between local events and market forces operating within and without the immediate environment. If tacit knowledge is at hand, myopic market participants are not able to make meaning out of that information. By contrast, sophisticated market participants are deemed to have the knowledge and experience to make sense of the flow of events, recognising the interplay between what happens in local and global financial markets. Sophisticates have a long-term perspective and a conceptual understanding of market structure and performance (bottom right-hand box). ${ }^{3}$

\section{[INSERT FIGURE 1 ABOUT HERE]}

According to the logic underpinning Figure 1, there may be investors that hold to a long-term perspective but do so without understanding the interaction effects between

3\%. Mullainathan $(2007,91)$ observed that sophisticates recognise that a long-term commitment to saving and investment must be governed in relation to short-term temptation and the possibility that plans may have to be re-made to deal with unanticipated events that require re-casting objectives. 
local markets and global markets. For Mullainathan (2007, 91), naïve planners tend either to hold too long to past commitments or abandon those commitments when events turn against expectations (upper right-hand box). Under- and over-reaction to market movements is characteristic of many market players, just as a lack of perspective about the origin and transmission of market movements may mean that they respond to 'local' signals without understanding the broader context. As important are the 'opportunists' that focus upon short-term market movements, moving between markets as arbitrage opportunities are presented. These investors care little about tacit knowledge; their skill is all about being able to exploit minor differences between markets against expectations utilizing leverage in relation to markets' momentum (bottom left-hand box).

Hilton (2003) and Shiller (2000) contend that a predisposition in favour of recent events often translates into herd behaviour, amplifying short-term market movements while threatening those that stay too long in the market with lower returns than those able to judge short-term movements against long-term local and global patterns. Nonetheless, myopia and opportunism are commonplace in financial markets made so, in part, by the incentives offered the employees of financial institutions. This point is developed below. We should also observe, though, that the extent to which market players are able to distinguish between the risks and rewards due to their employment and the risks and rewards attending their long-term welfare, market participants may be 'opportunists' and 'sophisticates' in different settings. See Clark et al. (2006) showing that pension fund trustees' risk appetite varies according to their responsibilities and their personal interests.

\section{Finance, Contingent Income, and Risk}

In a similar vein, Langley (2008) sought to bring global finance to ground: to the everyday networks of financial relationships and commitments that dominate individuals' lives. His point was that the geography of finance is simultaneously local and global penetrating to the smallest nook and cranny of the Anglo-American world while being intimately linked with market arbitrageurs operating around the world. His examples were both mundane and compelling, linking, for example, individual deposit and savings accounts to world-wide processes of risk-pricing. In this domain, individuals not only must plan for the future, they must also 'price' the risks of 
competing financial institutions and instruments on a global basis so as to hedge the risks that they are neither able nor willing to carry into the future. In effect, their risk 'appetite' and their capacity to manage those risks are constitutive elements of their long-term prospects.

For Langley, exposure to the market permeates everyday life to such an extent that people have come to internalise the norms of personal responsibility for retirement welfare. For some writers, this is representative of larger political forces that have conspired to discount the post-war welfare state and re-write the social contract, putting in play 'social goods' that were deemed to be best provided outside of the market (see Smith 2005). This resonates with continental European commentaries and criticism, being an issue that is part of a continuing debate over the reach of Anglo-American market institutions into the fabric of European society (Boyer 2001; Engelen 2003). In the Anglo-American world, markets play a greater role in allocating social resources than 25 or even 10 years ago. Nation-states are dwarfed by the financial institutions and markets to which they play host not withstanding the pivotal role of government in bailing-out failing financial institutions.

Were the UK housing boom just an issue of demand and supply, resolved in the manner of the housing boom of the late 1980s, this paper would have been about market structure and performance. But over the past ten years or so, property has figured prominently in the public imagination as a valuable asset class for retirement saving and investment. As Strauss (2009a) notes, in the years leading up to the subprime crisis, the popular press was awash with stories to the effect that property is an attractive alternative to conventional employer-sponsored retirement schemes. ${ }^{4}$ If highly problematic given recent events in global financial and mortgage markets, the dramatic shift in the UK private sector from DB to DC and personal pension plans gave weight to the argument that individual exposure to the risks associated with securities markets ought to be balanced by other kinds of investments including

\footnotetext{
4 . In one Sunday newspaper, a regular feature of their money and personal finance section is an interview with a 'public' person as regards their spending, saving, and pension behaviour. One of the questions posed to interviewees is whether it is better to invest in property or in a regular pension. Rarely, if ever, does the person interviewed report a preference for a pension. Commonly, they respond by arguing that property is better than a pension because the property market is easier to understand.
} 
property. ${ }^{5}$ At issue, in part, is the extent to which respondents' retirement investment portfolios were diversified across a variety of more or less cross-correlated assets.

In this study, our respondents were XXXX defined contribution plan participants. Few would have carried a DB plan into XXXX, and few would have wished to be in a DB plan given anticipated employment prospects. In any event, their compensation packages combined a base salary with the promise of performance-related annual bonuses and stock options which were dependent, in part, on the nature of the jobs they performed, the company's profitability, and market movements. These types of compensation packages were very important in the finance and technology sectors for 'incentivising' valued employees (Teece 2000), even if senior executives claimed large unfunded defined benefit pensions upon termination. At the limit, our respondents were either directly involved in tournaments for jobs or sought to take advantage of the existence of these tournaments to enhance their bonuses. Not surprisingly, younger workers and employers believe DB pensions to be irrelevant to their short-term (but different) goals (see Clark and Monk 2008 for empirical research on this point and Roberts 2004 for a theoretical exposition).

Contingent compensation has also been identified as important in other UK sectors and in cohorts of workers typically younger than the baby boom generation. Dickens (2000) showed that the younger a male British worker the more likely he was dependent upon a 'transitory' element for his earned income (compared to the 'permanent' component attributable to human capital). Dickens also showed that this transitory component persists over time, being important in explaining yearly increasing levels of earned-income inequality in British society. Although his characterisation of occupation was crude, he demonstrated that individuals from socalled white-collar professions exhibited a larger transitory component compared to individuals from so-called blue-collar occupations. Extended by Kalwij and Alessie (2003), his research suggests that there is (or was) a market premium for younger,

\footnotetext{
$5 \%$ It is important to recognise at this juncture that in defined contribution plans, plan participants bare the risks associated with investing for their future retirement income. By contrast, in defined benefit plans, the plan sponsor bares the risks associated with realising the promised pension benefit (Clark and Monk 2008). This means, more often than not, that defined contribution plan participants are fully-exposed to financial market performance-a reality that is quite profound for those enrolled in such plans and about to retire in the midst of the global financial crisis.
} 
white-collar workers due to happenstance or social position and that this premium accentuates measured income inequalities as the effect of human capital dampens with age. ${ }^{6}$

The culture of contingent compensation has been about immediate reward and longterm leverage in favour of personal wealth. It is, or was, a male culture of risk-taking personally and professionally that has had as its goal the joint maximization of shortterm returns (subject to the parameters set by the firm in relation to its market position). ${ }^{7}$ Few employees expected to be with the same firm in five years time, and even fewer expected to be in the industry at age 50. As it happens, there were significant long-tail (negative) risks in these situations. One was unknowingly accepting counter-party trades that exploited the bank's risk-controls thereby endangering job tenure and bank solvency. Another was being seduced by the prospect of wealth such that base salaries were willingly discounted in favour of 'promised' windfalls. Yet another was the possibility that salaries and bonuses were so highly correlated with market movements that retirement investment portfolios had the same risk profiles as current and expected earned income.

\section{Patterns of Earned Income and Market Volatility}

Bonuses in the finance industry were paid against market performance implying an autoregressive (AR) year-to-year carry-over effect, as indicated by run-ups in stock market performance. There were also significant stochastic elements (MA) as illustrated by unexpected market movements over the quarters since the 2007 peak of the boom. Dickens (2000) and Kalwij and Alessie (2003) suggested that the persistence of the transitory component has tended to increase over time especially for younger age cohorts. Looking back over the past 20 years and, in particular, the period 2001-2007 which saw the run-up in UK house prices, in this section we determine whether (1) growth in earned income and market movements can be

\footnotetext{
$\%$ This is one side of the polarization of UK real wage growth over the past 20 years. See Goos and Manning (2007) for the definitive treatment of UK wage inequality and their framework applied to the London labour market by May et al. (2007). Immigration has also played an important role in the recruitment of labour to the London financial industry at both ends of the wage and skill spectrum (see McDowell et al. 2008, 2009).

7 \% McDowell (2008) provides a revealing assessment of gendered roles and responsibilities. Note, though, our results do not hinge on gender so much as age and income (where, of course, most older, higher income employees were men).
} 
segmented into distinct periods such as 1988-2000 and 2001-2007; (2) whether their paths can be approximated by statistically similar ARIMA processes; and, (3) whether growth in income, housing, and stock market movements over the period 1988-2007 can be shown to have been significantly cross-correlated.

\section{Stability of mean annual growth rates}

A set of income series was collected from the Office of National Statistics (ONS) on individuals' quarterly earned income, other earned income including returns on investment and property, and total income (sum of the two). As for securities markets, the daily FTSE100 index was used to represent the path of stock price movements and the monthly Nationwide Building Society House Price index was used to represent the path of housing prices. All series were transformed into quarterly rates of growth or log differences and discounted by the Bank of England consumer price index. ${ }^{8}$

In Table 1 the mean annual growth rates for all five series are displayed, with a distinction made between the whole period 1989 (Q1) to 2007 (Q2) and the two subperiods pre-2001 and post-2001. A t-test was used to determine whether to reject the hypothesis that series' mean real growth rates were statistically the same before and after 2001. Table 1 reports these results, indicating that this hypothesis could not be rejected for 3 of the 5 series, this is despite the fact that income growth rates were higher in the post-2001 period and volatility in each of these series was lower in the post-2001 period, whereas the FTSE100 growth rate was much lower (negative) with a higher variance. ${ }^{9}$ The hypothesis of similarity was rejected for the FTSE100 and house prices; there was a significant difference between the pre- and post-2001 growth in house prices with a much lower variance in post-2001 growth rates. This relatively simple test of means and variance suggests a UK housing bubble possibly amplified by the stock market with implications for retirement portfolios.

\footnotetext{
8\% Data was found at www.statistics.gov.uk, www.uk.finance.yahoo.com, www.nationwide.co.uk/hpi and www.bankofengland.co.uk

$\%$. Not reported, but available from the authors, are the results of a t-test on series' standard deviations which showed that the variances of 4 of the 5 series were found statistically different between subperiods except for the FTSE100.
} 


\section{INSERT TABLE 1 ABOUT HERE]}

\section{Modelling income and market movements}

The next step in the analysis was to estimate ARIMA models of the five series. Table 2 summarizes the results of these estimations for the entire period 1988-2007. As we should expect from Dickens (2000), the income series combine significant autoregressive terms with effects spread over 3 quarters in two of the three series and a significant and positive stochastic component two quarters prior to the present value. In this respect, earned income and other income have 'memories' that tend to reinforce the path of growth in income as well as event-specific shocks that also contribute to growth. By contrast, the FTSE100 series contained only AR elements, specifically lags over one and two quarters.

\section{[INSERT TABLE 2 ABOUT HERE]}

UK house-price growth can be also approximated by an ARIMA model with significant AR terms distributed over three past quarters and a past quarter positive shock parameter. Given indications of bubble-like growth rates subsequent to 2001 in the difference of means test, we also estimated ARIMA models for house prices before and after 2001. It was found that the post-2001 series was not stationary and could be modelled as a random walk (the unit root hypothesis can not be rejected). ${ }^{10}$ See Table 3. A test of the boundary sensitivity of these results, shifting the first episode to 1988-1999 and re-defining the second episode as 2000-2007, did not change the results. We have evidence of a bubble in house price growth over the period 2001-2007, reinforcing the findings of Leamer (2007) and Taylor (2008) about the consequences for housing markets of highly expansionary monetary policy in the aftermath of the TMT bubble and 9/11.

\section{[INSERT TABLE 3 ABOUT HERE]}

So as to determine whether the series were statistically related, we created a correlation matrix of all series based upon quarter-to-quarter growth rates. In Table 4,

\footnotetext{
10\% Note also in Table 3 the differences between 1989-2000 and 2001-2007 in the Dickey Fuller test of the unit root hypothesis.
} 
the correlations between series are displayed for the entire period, for 1989-2000, and for 2001-2007 with their associated levels of significance. Clearly, the income series were highly correlated, with a higher variance in other income. More interesting was the fact that income series, house prices, and the FTSE100 were also statistically and positively cross-correlated for the entire period and for 1988-2000. These patterns are not so obvious in the second period 2001-2007 where house price growth was negatively correlated with income series and the FTSE100. The reader is reminded that all series were expressed in real terms suggesting a lower rate of growth in real incomes compared to the high rate of growth in house prices. Significantly, over this same period other income was shown to be statistically and positively correlated with the FTSE100 index.

\section{[INSERT TABLE 4 ABOUT HERE]}

These results provide a number of insights and implications. First, there is statistical evidence in favour of a UK house-price bubble, 2001-2007 (cf. Nickell 2005). Second, the bubble is expressed in higher rates of growth in house prices than real incomes (which were also growing but not at the same rate). Third, the coincidence and cross-correlation of series' growth rates prior to 2001 suggest an intimate relationship between earned incomes and financial markets, less evident though over the period 2001-2007. Those sophisticated long-term planners, conscious of the whole-period relationship between series, could have seen positive cross-correlations between series as a prompt to diversify retirement investment. The negative crosscorrelation between house prices and income in the second period might also have encouraged further investment in housing by those seduced by expectations- the housing bubble being amplified by its strong performance post-2001 relative to the performance of stock prices over the same period.

\section{Retirement Investment and Portfolio Diversification}

Notwithstanding the behavioural logic underpinning the paper, the cross-correlations between income, stock markets and property markets could be viewed through the lens of the permanent income hypothesis (Samuelson 1969). Here, three threads of theory overlap to underpin this claim as a reference point for empirical analysis. At one level, the permanent income hypothesis can be invoked to set the context for 
decision-making both with respect to current and expected long-term consumption. At another level, a human capital model of earned income can be invoked to provide cohort-specific respondents a time horizon over which to estimate expected earned income. Further, a life-cycle model can be invoked to establish a mechanism for judging the significance of current events against expected income and plans for retirement consumption. In these ways, current events can be set within an overarching time-dependent long-term optimization framework with implications for current and future retirement portfolio design (Merton 1969).

To make this argument work, however, heroic assumptions have to be made about the time horizon of behaviour, individuals' discount rates, stable incomes, and market structure. Many question the plausibility of each and every element in this chain of reasoning. For example, Deaton (1994) raised doubts about the plausibility of the permanent income hypothesis; empirical evidence on individuals' discount rates do not support standard assumptions prompting attempts to produce multi-attribute models (Ainslie 2001; Laibson 2003); Dickens (2000) showed that current incomes have a significant stochastic component; and, more troubling, Heaton and Lucas (2000) note that standard models assume that income is not significantly correlated with stock returns and other assets such as housing whereas we show above that there may be significant cross-correlations, especially in periods that carry high levels of risk and uncertainty. Even if people had the cognitive and social resources necessary to integrate time and space in a continuous optimizing framework, market structure would limit their ability to execute desired insurance strategies. ${ }^{11}$

As noted above, we are neither idealistic about behaviour under risk and uncertainty, nor are we convinced that people necessarily know and act according to their longterm best interests (see Clark et al. 2009 showing that whether people plan for the future and the geographical scale at which they make plans are correlated with age, income, and household status). So what do people do in these circumstances? How do they utilise complementary mechanisms of investment in designing their retirement portfolios? How did they manage bubble-driven asset classes like property

\footnotetext{
11\% Shiller's (1993) argument about the enormous welfare costs of incomplete markets applies in these circumstances. His argument was framed in relation to his experience in a housing boom and bust through the mid 1980s and early 1990s. His experience prompted a close examination of the psychology of markets amongst other topics.
} 
in relation to the other forms of retirement investment? In working through the empirical evidence on the intended construction of their retirement portfolios, were most people myopic or were there sophisticated long-term planners that seemed to be aware of the risks of property investment in diversifying their retirement portfolios? These questions frame analysis reported in this section and in the following sections.

Our research is based on a specially designed and implemented May 2007 survey of employees from a large London-based multi-national investment company (XXXX) at the peak of the bubble and before the on-set of the global financial crisis. We drew younger, higher income, and higher educated respondents than is normally the case, all with responsibility for setting the parameters for long-term investment in their employer-sponsored defined contribution pension plan. The questionnaire was designed to match, in part, previous research on related issues of pension planning and decision-making in collaboration with Mercer Human Resource Consulting (for more details see Clark and Strauss 2008). Of approximately 7000 London-based employees, 2372 responded to the on-line survey. The survey was based on 31 structured questions that set common response-options and sought information on conventional socio-demographic characteristics including income, age, gender, and household circumstances; expressed attitudes to statements of opinion or intention normally assessed using a 5-point Likert scale; and, puzzles or problems to be solved focused upon asset allocation.

There is debate in the social sciences over the robustness of surveys and puzzlesolving, given the tendency of respondents to answer in ways that oftentimes anticipate researchers' expectations. Some researchers distrust expressed attitudes and opinions while others are doubtful about the relevance of solving puzzles suggesting responses may be rather ephemeral if not anchored in a certain domain with specific tasks and pay-offs. These are reasonable concerns. But they can be overplayed in situations where respondents are knowledgeable about the issues and whose employment tasks and functions are related to the issues at hand. Moreover, there is evidence that in domain-specific tests of opinion and intended action there is a close relationship between expressed preferences and behaviour (see Dohmen et al. 2005; Dorn and Huberman 2005; Weber et al. 2002). 
So as to establish a base-line against which to understand the significance of property for our respondents, the analysis proceeded in two stages focused upon the nature and scope of respondents' non-pension retirement savings. The following question was posed to all respondents: "Apart from the XXXX pension scheme what are the other ways by which you save for your retirement, if any? Please check all that apply." This question came early in the questionnaire following a series of questions brought together under the banner of retirement planning. Options for retirement savings included (in order of their significance for respondents): savings accounts (71.9 per cent of respondents checked this option), other savings (such as PEPs, ISAs, equities) (67.3 per cent), occupational pensions from a previous employer (43.2 per cent), property investments (eg. buy-to-let, second home) (30.7 per cent), other XXXXsponsored savings and/or deferred compensation schemes (20.0 per cent), insurance related savings (eg. endowments) (15.2 per cent), and other (9.0 per cent). ${ }^{12}$

In the first instance, the dependent variable was the number of asset classes identified by respondents (0-7): that is, the diversity of their retirement savings portfolio leaving aside their current employer-sponsored DC plan. Here, socio-demographic variables including age, income, gender, and household status were used as explanatory variables for portfolio diversification. Notice, though, social scientists are properly cautious of inferences to the effect that socio-demographic status is causal: that is, by age, gender, and income people behave in predictable ways. Nonetheless, we have shown that age, income, and family status are closely related to the sophistication of pension planning especially for older employees who have much to gain or much to lose by becoming involved in pension planning (Clark et al. 2009). As well, these variables have proven important in other studies of UK retirement planning and engagement in asset allocation decisions (Clark and Strauss 2008). Having the confidence and capacity for pension planning is clearly important especially in diverse populations with different levels of knowledge and understanding of the links between pension saving and the nature and purpose of various financial instruments.

\footnotetext{
$12 \%$ In the survey, we sought to distinguish respondents' owned-occupied homes from investment in the property markets including tax-preferred buy-to-let housing. A home is a complex idea, being a proxy for children's desired schooling, a status good, a consumption item, an insurance against catastrophic illness, and an intended bequest to children. If it is a pension investment, this suggests that people intend to go into either the sale of the family home during retirement or some form of equity release. However, it is widely appreciated that neither options are preferred by current UK retirees. See Smith (2008) on the many interpretations attributed to the 'family home'.
} 
Following these findings, we estimated the effects of respondents' attitudes and opinions on the number of instruments in their investment portfolios. This was done in the light of widely-recognised recommendations by finance academics and professionals to the effect that the diversification of long-term risk across asset classes is one important function of a retirement savings portfolio (Sharpe 2007). From modern portfolio theory (Markowitz 1952) and behaviouralism (Benartzi and Thaler 2001) also comes the hypothesis that an expressed preference for risk aversion is properly correlated with a larger number of asset classes (see more generally Litterman et al. 2003). ${ }^{13}$

Table 5 reports the results of an OLS regression where the dependent variable (number of additional savings instruments) is set against socio-demographic status, statements of belief, and an expressed preference for risk. It is shown that the closer respondents were to retirement the larger the number of investment vehicles, respondents with a spouse with a similar pension entitlement were associated with a larger number of investment instruments, and the more junior a respondent the fewer the number of instruments. However, being risk tolerant was associated with more savings instruments, a finding not entirely consistent with theoretical expectations to the effect that risk aversion would be associated with a larger set of savings instruments. ${ }^{14}$ Those lacking confidence in retirement planning tended to have fewer savings instruments whereas those more confident had more savings instruments. It was difficult to interpret the finding that those who agreed or disagreed with the statement that they rely upon "someone else to support" them in retirement implied more savings instruments.

\section{[INSERT TABLE 5 ABOUT HERE]}

\footnotetext{
13\% Risk-management is framed here as an issue of portfolio diversification. As Paul Langley (pers. com.) has noted, this is a partial view considering that some respondents may have been parties to derivative products designed to dampen the risks associated with holding property. While possible, we would note that access to such products on an individual basis is rare, and very expensive.

14 . Those deemed risk tolerant (38.3 per cent of respondents) were those that checked the option "I aim to get the best possible growth in the value of my savings, even if that means taking the chance that I could lose money." By contrast, those deemed risk averse were those that "prefer to have safe and secure savings and investments, even if that means they do not grow in value as much as they could." This is a variation on Kahneman and Tversky's (1979) formulation of risk aversion although not formally tested in an experimental situation.
} 
These findings are consistent with findings for a representative sample of UK residents regarding the correlates of pension planning and the demand for consultation in pension investment (see Clark et al. 2009; Clark and Knox 2009). As noted above, it is not surprising that older people with spouses also involved in pension planning have a broader range of retirement investment instruments than others not so 'located' (using Sharpe's 2007 term). This may be because they could afford to do so or because they realised the importance of managing risk given pending retirement. Equally, the issue is more salient to them than is perhaps the case for younger, lower income employees without the advantage of a joint interest in future welfare.

\section{Property and Portfolio Diversification}

We sought to determine whether there was anything distinctive about those respondents who expressed a preference for property, recognising that about 25 per cent of respondents were so inclined. In Table 6, we summarize the pattern of a property preference noting that only 65 of 2,372 respondents would have relied exclusively on property as an additional investment instrument to their XXXXsponsored defined contribution plan. The table also shows that property in combination with other savings instruments was not particularly popular, recording 624 responses out of 2,372. Even so, there were some respondents who would have loaded-up on property by limiting the combination of property with other instruments; the most popular combinations were property +1 , property +2 , and property +3 savings and investment instruments.

\section{[INSERT TABLE 6 ABOUT HERE]}

\section{Determinants of a bias towards property}

Here, the dependent variable was set as including property $(=1)$ or not $(=0)$. The results of a probit regression are summarized in Table 7 . Note the parameters are expressed as marginal probabilities. Curiously, it is easier to identify the negative case (excluding property) as opposed to the positive case (including property). The negative sign on the estimated parameters suggests that those separated and those in relatively low-status jobs as well as those who agreed with the statement that the house they live in "will provide the majority of retirement needs" and those who 
agreed with the statement that they would like to do more for retirement but could not afford to do so tended not to include property in their portfolios. These are plausible responses. Equally plausible are the positive results on risk tolerance and those who disagreed with the statement that they would rely upon someone else for their retirement. Harder to understand is the significant and positive parameter on gender (being female=1) (compare with Watson and McNaughton 2007).

\section{[INSERT TABLE 7 ABOUT HERE]}

We can summarize the results presented in Table 7 in the following manner: those who were risk tolerant and self-reliant for future retirement income were predisposed to include property in their savings portfolios whereas those by dint of family status, (lower) job status, and disposable income were not so predisposed. Remarkable was the finding that property was not significant (one way or another) by age, income, spousal pension or recognition that planning for retirement is important. The variables shown as crucial to UK pension planning were not significant for the choice of property as a retirement savings instrument (compare Clark et al. 2009).

\section{Property in combination with other instruments}

What of the role of property in combination with other savings instruments? Can we identify correlates for property and the number of associated savings instruments? Table 8 summarizes the results of an Ordered Logit (OL) regression where the dependent variable was property plus alternative savings instruments (five groups in total as displayed in Table 5).

\section{[INSERT TABLE 8 ABOUT HERE]}

In this instance, the objective was to estimate the probability of belonging to any of the 5 groups focusing upon the statistical significance and sign (positive and negative) of the socio-economic determinants. With respect to socio-demographic variables we found age and income to be significant: the two older age categories 40-49 years and 50-59 years (wherein the latter group has the largest parameter) and the two higher income categories medium and high income (wherein the former had the larger parameter value). The sign on age is positive implying a bias towards property with 
more savings instruments whereas the sign on income is negative implying a bias towards property and fewer savings instruments relative to the five or more instruments (holding constant other effects). Clearly significant in this case were affirmative results on planning for retirement, being confident about doing enough for retirement, and relying upon others for support during retirement. In each case, the positive sign on "agreement" indicates a bias towards holding property with more savings instruments. Finally, with respect to risk-taking, again a positive sign was found for those who indicated risk tolerance.

\section{[INSERT TABLE 9 ABOUT HERE]}

The results reported above are summarised in Table 9 by the estimated probability of respondents belonging to any of the 5 groups (ignoring those variables not found to be significant on any or all elements within). With respect to age, the probability of belonging to any group for 40-49 year olds was biased to property +2 and property +3 whereas for 50-59 year olds the probability of belonging to any group was centred on property +3 . For income, the bias for medium and high income earners (holding all other effects constant) was somewhat different with medium earners centred on property +1 and high income earners on property +2 . Those who believed planning for retirement was important, were confident, and would rely upon others, are centred (respectively) on property +2 , property +3 and property +6 . Finally, those indicating risk tolerance were centred on property $+2 /$ property +3 .

\section{Synthesis and Interpretation}

Just as the housing bubble was losing momentum, our survey sought evidence about the nature and scope of respondents' intended retirement savings and investment strategies. We were especially interested in their holistic approach to the issue, recognising that few studies of pension investment step outside the parameters of offered pension schemes to include other components of household wealth. Most importantly, we sought to determine whether our respondents were sophisticated investors balancing the risks in income, securities markets and property with other instruments not so obviously cross-correlated with short-term financial movements. Given their position in the London and global financial industry, one hypothesis was that their intended retirement investment strategies would take account of these risks 
and be appropriately diversified. The alternative hypothesis was that they too were caught-up in the irrational exuberance attending the housing bubble, attributing great significance to property investment in their whole portfolios.

To sustain the analysis, we began with the macro-movements of national income, the London stock market and the UK House Price index. Here, as expected, we found significant and consistent levels of cross-correlation with evidence that the houseprice boom was, in fact, a bubble amplified by the stock market. Given that compensation in the London financial industry carried a large 'performance' component with rewards such as stock options, there can be little doubt as to the riskexposure of our respondents to market movements. Having asked respondents to choose amongst 7 savings and investment options other than the XXXX defined contribution pension plan, an important finding was that respondents were rather cautious about other investments rating bank savings accounts above PEPs, ISAs and equities with due regard given to the pension plans of previous employers (43.2 per cent). Property came fourth in the list of options, being preferred over other XXXX deferred savings schemes and insurance products. Only 65 of 2,372 respondents chose to concentrate on property though 458 of the 624 who identified property as a desirable option would have held limited numbers of other investment instruments.

Assuming a sophisticated investor carries a diverse portfolio of retirement investment instruments in circumstances where current income is highly contingent on market movements, we sought to identify the determinants of portfolio diversification. As expected, those that would carry a larger number of instruments were older, had a spouse similarly engaged in pension planning, were confident about pension planning, and were risk tolerant. Those that would carry a limited number of instruments held rather junior positions, earned average incomes (referencing bank standards), and lacked confidence in pension planning. It is arguable that those with diverse portfolios were those who recognised the importance of pension planning by reason of their age and immediate prospects (regardless of income). Equally, it is arguable that those with a more limited set of instruments were unable to manage their long-term risks notwithstanding their recognition of the apparent risks involved. 
Of those respondents who chose property (yes $=1$, no=0), the significant positive coefficients were gender, self-reliance, risk tolerance and (lower) income. This suggests either a group of people who were rather self-confident about their own ability and/or a group of people who believed that property was the only viable option (given their limited options). The negative coefficients were, once again, those in relatively junior positions and those who indicated that they were simply not able to afford to save for retirement. What of the coefficients on property-centred diverse portfolios of retirement instruments? Once again, those respondents who combined property with a larger number of instruments were older, recognised planning for the future was important, were confident, and were risk tolerant. It was more difficult to characterise those who combined property with a limited number of instruments.

It is significant that age, income, and planning capacity all figured in affecting the probability of being in any of the five groups. This result suggests a level of conscious deliberation and choice wherein property and its related instruments were chosen for strategic reasons having to do with forecast and pending retirement. Those disenchanted or unable to plan by virtue of a lack of confidence or a lack of capacity did not appear to use property in a strategic manner.

We would contend that many of our respondents were sophisticated investors. Even if they could not have known the full extent of the global crisis in mortgage markets and the resulting decline in UK and global housing prices let alone the cataclysmic events of late summer 2008, respondents took a safety-first approach to long-term risk (see Roy's 1950 seminal paper). Those most at risk to market turmoil and those with most to gain and lose from market movements in relation to their immediate plans for retirement appeared to be the most savvy investors; older, confident retirement planners had the broadest portfolios and tended to combine property (to the extent they deemed it a valuable instrument) with other instruments.

By contrast, there were some respondents who by dint of a lack of alternatives seemed to concentrate on property. If they recognised the likely risks associated with the housing bubble, they may have had few other options given their age and income, their stage in careers, positions in the firm, and lack of savings. Safety-first is an option only if respondents have the resources, experience, and judgement to back their 
retirement plans. Without options, even those conscious of the looming costs of the 'bubble' may have been trapped in the property market.

\section{Conclusions}

In this paper, we focused on the retirement savings and investment strategies of wellplaced individuals, being both employees of a large London-based multinational investment company (XXXX) and participants in that company's defined contribution plan. Whereas many studies of portfolio diversification consider the range of options and choices made within the bounds of DC plans, we looked outside of the employersponsored plan to the whole retirement portfolios of employees noting that recent research has suggested that a complete picture is necessary when seeking to understand individual retirement savings (Clark et al. 2009). Emphasized, as well, were the cross-correlations between current income, the stock market, and the UK housing market, hypothesizing that sophisticated investors would dampen the concentration of risks by diversifying their retirement investment portfolios.

Modelling macro-movements in incomes and markets, we showed that the bubble was apparent in the path of house prices over the period 2001-2007. Many of our respondents pursued a safety-first retirement savings strategy thereby either deliberately or in response to market pressure discounting the transfer of market and income risks into their retirement investment strategies. Property was not a significant component of many respondents' strategies; very few of our respondents concentrated on property as a desired form of retirement savings. Our respondents were savvy investors, and were not caught up in the irrational exuberance that seemed to dominate expectations of the proper role of property in UK residents' retirement plans (see Smith 2008; Strauss 2009a). Against public expectations, we would suggest that their safety-first retirement savings strategy reflected tacit knowledge and experience in financial markets.

We noted that age, income, confidence in retirement planning as well as risk tolerance were significant determinants of a diverse savings portfolio whether across all retirement savings instruments or with respect to a property-centred savings portfolio. By contrast, junior employees (by job classification), lower income employees (against the standards of the finance industry), and those less confident in retirement 
planning and not advantaged by having a spouse similarly placed with respect to pension entitlement, tended to have less diverse savings portfolios and, in those cases where property was important, more reliance on property to the exclusion of other instruments. It could be argued that these results amplify and are consistent with previous results to the effect that salience and sophistication tend to be associated with pension planning; those by dint of age and income who have most to lose from rash investment decisions are those most focused on pension planning and investment decision-making (Clark et al. 2009; Clark and Knox 2009).

But there is an unresolved issue of cause and effect embedded in the results. Are older, higher income individuals more effective retirement planners and risk managers because of their apparent reliance upon investment decisions taken now and in the immediate future or are they more likely to pursue the safety-first option because they are older with higher individual and household incomes? Does age and income enable effective retirement investment and planning because they have the resources to do so (unlike younger, more junior employees who tend not to have the benefits of higher incomes and accumulated wealth and resources)? Many of our respondents were younger. Compared to their peers in the industry their base salaries were lower, even if they would have benefited from bonus and stock-option windfalls. If better off than the average UK worker, disposable incomes were likely highly constrained by expenses associated with their children's education, mortgage payments on the family home, and the repayment of education fees. It could be that their savings portfolios were limited by their commitments in ways that 40 and 50 year olds are not.

Lacking significant savings, being unable to afford ISAs, PEPs and related investments, and being nervous of the high cross-correlations between their earned income and the path of the stock market they may have seen property other than the family home as the only alternative (especially when buy-to-let carries tax-preferred rental income). By this account, our respondents may have been savvy in two senses: at one level recognising the ideal strategy if they had the savings and wealth to do so and, at another level, knowingly taking a gamble on property given it was the only option that might provide a pay-off large enough to switch gears later on in favour of the safety-first option. By this logic, they were the agents in social theory (see Preda 
2004) even if unlikely so given the findings of our research on the age-bias of pension planning (Clark et al. 2009).

Consequently, we finish with the four types market players introduced in Figure 1 (above). There were sophisticated investors who discounted the related risks by a safety-first investment strategy; opportunistic investors who took a gamble on the path of house prices relying upon inside information to cut-and-run from the market as soon as it turned down; naïve planners caught-up in the irrational exuberance of the moment notwithstanding a range of intended long-term savings options; and, myopic investors who by lack of income and lack of knowledge of the cross-correlations between macro-movements in financial markets over-loaded on property and stayed too long in the property market, following the market down as they had followed the market up. Amongst our respondents, all four types of investors may have been present. But it would seem that most were either sophisticates or opportunists. Few were naïve or myopic_ — a finding consistent with Gertler's thesis of 'being there' (contra O'Donoghue and Rabin 1999). This is further evidence of a differentiated map of British pension savings, advantaging market insiders in London over residents from other regions (see Sunley 2000).

This paper can be read, therefore, as an empirical demonstration of the argument advanced in Strauss (2009b) to the effect that there is an intimate, even reinforcing relationship between behaviour and context (or what Simon 1956 and Sharpe 2007 have referred to as the 'environment' in which behaviour takes place). It demonstrates that 'being in the market' can reap dividends; it also suggests that the location of market agents whether amateurs or experts can frame the conceptualisation of risk and set the options available to those agents. As suggested by Engelen (pers. communication), there are larger forces at work including the transformation of what counts as state and individual responsibility of planning for the future. In part, this is a political project set within structural constraints including the ageing of developed economies' populations. One implication from our research is that 'being in the market' may reinforce emerging income inequalities in earned income by amplifying those inequalities through the differential responses of people to market movements. These issues have been barely acknowledged by governments in their rush to embrace the new order of personal pension planning. 


\section{References}

Ainslie, G. 2001. Breakdown of Will. Cambridge: Cambridge University Press

Arrow, K. J. 1986. Rationality of self and others in an economic system. Journal of Business 59: S385-99

Baron, J. 2008. Thinking and Deciding. $4^{\text {th }}$ Edn. Cambridge: Cambridge University Press

Benartzi, S. and Thaler, R. 2001. Näive diversification strategies in defined contribution savings plans. American Economic Review 91:71-99

Boyer, R. 2000. Is a finance-led growth regime a viable alternative to Fordism? A preliminary analysis. Economy and Society 29:111-45

Christie, H., Smith, S. J. and Munro, M. 2008. The emotional economy of housing. Environment and Planning A 40:2296-312

Clark, G. L. 2010. Human nature, the environment, and behaviour: the scope and scale of financial decision-making. Geografiska Annaler B (forthcoming)

Clark, G. L. and Knox-Hayes, J. 2009. The new paternalism, consultation and consent: expectations of UK participants in defined contribution and self-directed retirement savings schemes. Pensions: An International Journal 14(1):58-74

Clark, G. L., Knox-Hayes, J. and Strauss, K. 2009. Financial sophistication, salience and the scale of deliberation in UK retirement planning. Environment and Planning A (forthcoming)

Clark, G. L. and Monk, A. H. B. 2007. The "crisis" in defined benefit corporate pension liabilities Part I \& Part II. Pensions: An International Journal 12(1):43-54; 12 (2):68-81

Clark, G. L. and Monk, A. H. B. 2008. Conceptualizing the defined benefit pension promise. Benefits Quarterly 25(1):7-18

Clark, G. L. and Strauss, K. 2008. Pension-related individual risk propensity, and the effects of socio-demographic characteristics and a spousal pension entitlement. Ageing and Society 28:847-74

Deaton, A. 1992. Understanding Consumption. Oxford: Oxford University Press

Dickens, R. 2000. The evolution of individual male earnings in Great Britain: 197595. Economic Journal 110:27-49

Dixon, A. and Monk, A. 2009. The power of finance: global influence with local differences. Journal of Economic Geography (forthcoming) 
Dohmen, T., Falk, A., Huffman, D., Sunde, U., Schupp, J. and Wagner, G. G. 2005. Individual risk attitudes: new evidence from a large, representative, experimentallyvalidated survey. Discussion Paper 1730. Bonn: Institute for the Study of Labor. See http://www.iza.org/en/webcontent/publications/papers/viewAbtsract?dp_id=1730

Dorn, D. and Huberman, G. 2005. Talk and action: what individual investors say and what they do. Review of Finance 9:437-81

Engelen, E. 2003. The logic of funding European pension restructuring and the dangers of financialization. Environment and Planning A 35:1357-72

Gabaix, X., Laibson, D., Moloche, G. and Weinberg, S. 2006. Costly information acquisition: experimental analysis of a boundedly rational model. American Economic Review 96:1043-68

Gertler, M.S. 2003. Tacit knowledge and the economic geography of context, or the undefinable tacitness of being (there). Journal of Economic Geography 3:75-99

Goos, M. and Manning, A. 2007. Lousy and lovely jobs: the rising polarization of work in Britain. Review of Economics and Statistics 89:118-33

Hamnett, C. 1999. Winners and Losers: Home Ownership in Modern Britain. London: Routledge

Hamnett, C. 2008. Spatially displaced demand and the changing geography of house prices in London, 1995-2006. Housing Studies (forthcoming)

Hamnett, C. and Whitelegg, C. 2007. Loft conversion and gentrification in London: from industrial to post-industrial land use. Environment and Planning A 39:106-24

Heaton, J. and Lucas, D. 2000. Portfolio choice in the presence of background risk. Economic Journal 110:1-26

Hilton, D. J. 2003. Psychology and the financial markets: applications to understanding and remedying irrational decision-making. In The Psychology of Economic Decisions. Volume 1: Rationality and Well-Being edited by I. Brocas and J. D. Carrillo. Oxford: Oxford University Press, 273-97

HM Government. 2007. Homes for the Future: More Affordable, More Sustainable. Department for Communities and Local Government $\mathrm{Cm}$ 7191. London: The Stationary Office

Kahneman, D. and Tversky, A. 1979. Prospect theory: an analysis of decisions under risk. Econometrica 47:263-91

Kalwij, A.S. and Alessie, R. 2003. Permanent and transitory wage inequality of British men, 1975-2001: year, age and cohort effects. Available at http://ssrn.com/abstract $=382780$ 
Laibson, D. 2003. Golden eggs and hyperbolic discounting. Quarterly Journal of Economics 62:443-77

Langley, P. 2008. The Everyday Life of Global Finance: Saving and Borrowing in Anglo-America. Oxford: Oxford University Press

Leamer, E. 2007. Housing is the business cycle. Working Paper 13428. Cambridge MA: National Bureau of Economic Research

Litterman, B. et al. 2003. Modern Investment Management. New York: Wiley

Markowitz, H. M. 1952. Portfolio selection. Journal of Finance 7:77-91

May, J., Wills, J., Datta, K., Evans, Y., Herbert, J. and McIlwaine, C. 2007. Keeping London working: global cities, the British state and London's new migrant division of labour. Transactions, Institute of British Geographers NS32:151-67

McDowell, L. 2008. Bodies out of place: unruly female bodies in professional occupations and trans-national body shopping. Mimeo. Oxford: Oxford University Centre for the Environment

McDowell, L., Batnitzky, A. and Dyer, S. 2008. Internationalizion and the spaces of temporary labour: the global assembly of a local workforce. British Journal of Industrial Relations 46:750-70

McDowell, L., Batnitzky, A. and Dyer, S. 2009. Precarious work and economic migration: emerging immigrant divisions of labour in Greater London's service sector. Economic Geography (forthcoming)

Merton, R. C. 1969. Lifetime portfolio selection under uncertainty: the continuoustime case. Review of Economics and Statistics 51:247-57

Mullainathan, S. 2007. Psychology and economic development. In Behavioral Economics and its Applications edited by Diamond, P. and Vartiainen, H. Princeton: Princeton University Press, pp. 85-113

National Audit Office. 2009. The Nationalisation of Northern Rock. London: HM Treasury

Nickell, S. 2005. Practical issues in United Kingdom monetary policy, 2000-2005. Proceedings of the British Academy 139:1-33

O’Donoghue, T. and Rabin, M. 1999. Doing it now or later. American Economic Review 89:103-24

Preda, A. 2004. The investor as a cultural figure of global capitalism. In The Sociology of Financial Markets edited by K. Knorr Cetina and A. Preda. Oxford: Oxford University Press, 141-62 
PricewaterhouseCoopers. 2006. Modelling UK house price uncertainty. Economic Outlook (November), pp. 16-23. London

Roberts, J. 2004. The Modern Firm: Organisational Design for Performance and Growth. Oxford: Oxford University Press

Roy, A. D. 1950. Safety first and the holding of financial assets. Econometrica 20:431-49

Samuelson, P. A. 1969. Lifetime portfolio selection by dynamic stochastic programming. Review of Economics and Statistics 51:239-46

Sharpe, W. F. 2007. Investors and Markets: Portfolio Choices, Asset Prices, and Investment Advice. Princeton: Princeton University Press

Shiller, R. J. 1993. Macro Markets: Creating Institutions for Managing Society's Largest Economic Risks. Oxford: Oxford University Press

Shiller, R. J. 2000. Irrational Exuberance. Princeton: Princeton University Press

Shiller, R. J. 2007. Understanding recent trends in house prices and home ownership. Working Paper 13553. Cambridge MA: National Bureau of Economic Research

Shiller, R. J. 2008. The Subprime Solution: How Today's Global Financial Crisis Happened and What to Do About It. Princeton: Princeton University Press

Simon, H. A. 1956. Rational choice and the structure of the environment. Psychological Review 63:129-38

Shleifer, A. 2000. Market Inefficiency. Oxford Oxford University Press

Smith, S. J. 2005. States, markets and an ethic of care. Political Geography 24:1-20

Smith, S. J. 2008. Owner-occupation: at home with a hybrid of money and materials. Environment and Planning A 40:520-35

Smith, S. J., Munro, M. and Christie, H. 2006. Performing (housing) markets. Urban Studies 43:81-98

Strauss, K. 2008. Re-engaging with rationality: the context of UK pension decisionmaking. Journal of Economic Geography 8:137-56

Strauss, K. 2009a. Banking on property for retirement? Attitudes to housing wealth and pensions. (forthcoming)

Strauss, K. 2009b. Cognition, context, and multi-method approaches to economic decision making. Environment and Planning A 41: 302-17

Sunley, P. 2000. Pension exclusion in grey capitalism: mapping the pensions gap in Britain. Transactions, Institute of British Geographers 25:483-501 
Taylor, J. B. 2009. Getting Off Track: How Government Actions and Interventions Caused, Prolonged, and Worsened the Financial Crisis. Stanford: Hoover Institution

Teece, D. 2000. Managing Intellectual Capital. Oxford: Oxford University Press

Watson, J. and McNaughton, M. 2007. Gender differences in risk aversion and expected retirement benefits. Financial Analysts Journal 63(4):52-62

West, R. R., McNabb, R. M., Thompson, A. G. H., Sheldon, T. A. and GrimleyEvans, J. 2003. Estimating implied rates of discount in healthcare decision-making. Health Technology Assessment 7 \#38 
Table 1. Comparison of Quarter-to-Quarter Annual Growth Rates and the Test of Differences, 1989-2007 (Standard Error in Parenthesis)

\begin{tabular}{|c|c|c|c|c|c|c|c|c|}
\hline & \multicolumn{3}{|c|}{ Mean of Annual Growth Rates ${ }^{/ 2}$} & \multirow[b]{3}{*}{$\square$} & \multirow{2}{*}{\multicolumn{4}{|c|}{ Differences in Means Tests }} \\
\hline & \multirow{2}{*}{$\begin{array}{c}\text { Whole } \\
\text { Period } \\
\mu\end{array}$} & \multirow{2}{*}{$\begin{array}{c}\text { Pre-2001 } \\
\mu_{1}\end{array}$} & \multirow{2}{*}{$\begin{array}{l}\text { Post } 2001 \\
\mu_{2}\end{array}$} & & & & & \\
\hline & & & & & $\mu_{1}-\mu_{2} / 2$ & t-statistic & Prob & Но $\mu 1=\mu 2$ \\
\hline \multirow[t]{2}{*}{ Total Income } & $2.90 \%$ & $2.80 \%$ & $3.10 \%$ & & -0.0030 & -0.4104 & $68.27 \%$ & Not Rejected \\
\hline & $(0.0299)$ & $(0.0351)$ & $(0.0169)$ & & $(0.0073)$ & & & \\
\hline \multirow[t]{2}{*}{ Wage Income } & $2.79 \%$ & $2.77 \%$ & $2.82 \%$ & & -0.0004 & -0.0715 & $94.32 \%$ & Not Rejected \\
\hline & $(0.0231)$ & $(0.0276)$ & $(0.0114)$ & & $(0.0057)$ & & & \\
\hline \multirow[t]{2}{*}{ Other Income ${ }^{/ 1}$} & $3.03 \%$ & $2.78 \%$ & $3.48 \%$ & & -0.0070 & -0.5999 & $55.05 \%$ & Not Rejected \\
\hline & $(0.0478)$ & $(0.0547)$ & $(0.0319)$ & & $(0.0117)$ & & & \\
\hline \multirow[t]{2}{*}{ UK House Index } & $3.44 \%$ & $0.12 \%$ & $9.58 \%$ & & -0.0946 & -4.6179 & $0.00 \%$ & Rejected \\
\hline & $(0.0951)$ & $(0.0959)$ & $(0.0557)$ & & $(0.0205)$ & & & \\
\hline \multirow[t]{2}{*}{ FTSE100 } & $3.12 \%$ & $6.66 \%$ & $-3.42 \%$ & & 0.1009 & 3.3248 & $0.14 \%$ & Rejected \\
\hline & $(0.1329)$ & $(0.0892)$ & $(0.1724)$ & & $(0.0303)$ & & & \\
\hline
\end{tabular}

Period: 1988Q1-2007Q2

${ }^{11}$ Includes gross operating surplus, employers social contributions, and property income.

${ }^{12}$ Standard errors in parenthesis 
Table 2. Models of Income and Financial Indicators, 1989-2007

Annual Growth Rates (difference in logarithms quarter to quarter)

(Standard Error in Parenthesis)

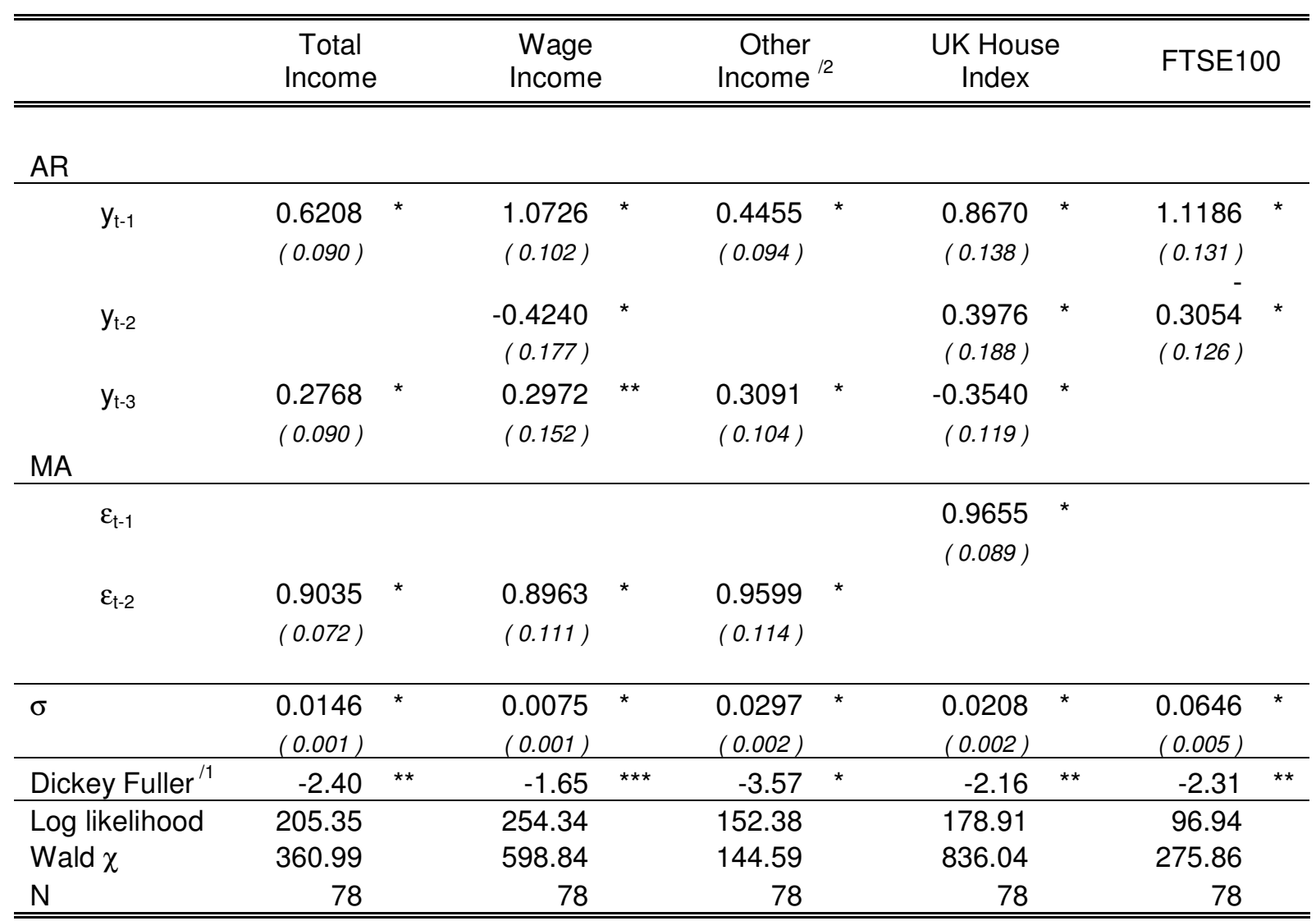

Significance level: * $1 \%,{ }^{* *} 5 \%,{ }^{* *} 10 \%$

Period: 1988Q1-2007Q2

${ }^{11}$ The unit root hypothesis is rejected at the significance level indicated by $\left({ }^{*}\right)$. No constant and one lag.

${ }^{12}$ Includes gross operating surplus, employer's social contributions, and property income. 
Table 3. Models of the UK House Index, 1989-2000 and 2001-2007 Annual Growth Rates (difference in logarithms quarter to quarter) (Standard Error in Parenthesis)

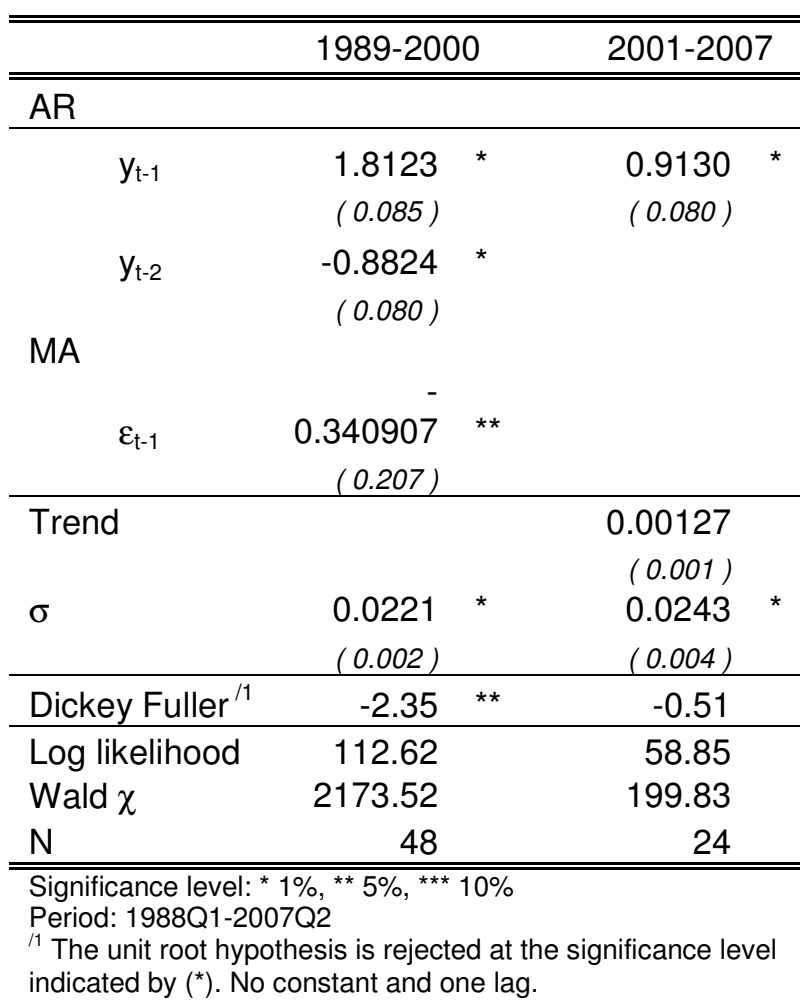


Table 4. Correlation Matrices of Macro-variables, Quarter-to-Quarter 1988-2007

\begin{tabular}{lcccccc}
\hline \hline $\begin{array}{c}\text { Whole Sample } \\
1988-2007\end{array}$ & $\begin{array}{c}\text { Total } \\
\text { Income }\end{array}$ & $\begin{array}{c}\text { Wage } \\
\text { Income }\end{array}$ & $\begin{array}{c}\text { Other } \\
\text { Sources of } \\
\text { Income }\end{array}$ & $\begin{array}{c}\text { UK House } \\
\text { Index }\end{array}$ & FTSE100 \\
\hline \hline Total Income & 1.000 & $0.857 *$ & $0.931 *$ & $0.487 *$ & 0.184 \\
Wage Income & $0.857 *$ & 1.000 & $0.610 *$ & $0.586 *$ & 0.158 \\
Other Sources of Income & $0.931 *$ & $0.610 *$ & 1.000 & $0.335 *$ & 0.171 \\
UK House Index & $0.487 *$ & $0.586 *$ & $0.335 *$ & 1.000 & -0.126 \\
FTSE100 & 0.184 & 0.158 & 0.171 & -0.126 & 1.000 \\
\hline \hline
\end{tabular}

Significance level: * $1 \%,{ }^{* *} 5 \%,{ }^{* * *} 10 \%$

\begin{tabular}{lcccccc}
\hline \hline $\begin{array}{c}\text { Pre 2001 } \\
\text { 1988-2000 }\end{array}$ & $\begin{array}{c}\text { Total } \\
\text { Income }\end{array}$ & $\begin{array}{c}\text { Wage } \\
\text { Income }\end{array}$ & $\begin{array}{c}\text { Other } \\
\text { Sources of } \\
\text { Income }\end{array}$ & $\begin{array}{c}\text { UK House } \\
\text { Index }\end{array}$ & FTSE100 \\
\hline \hline Total Income & 1.000 & $0.874 *$ & $0.934 *$ & $0.657 *$ & 0.228 \\
Wage Income & $0.874 *$ & 1.000 & & $0.641 *$ & $0.772 *$ & 0.337 \\
Other Sources of & & & & & & \\
Income & $0.934 *$ & $0.641 *$ & 1.000 & $0.469 *$ & 0.109 \\
UK House Index & $0.657 *$ & $0.772 *$ & $0.469 *$ & 1.000 & $0.515 *$ \\
FTSE100 & 0.228 & $0.337 * *$ & 0.109 & $0.515 *$ & 1.000 \\
\hline \hline
\end{tabular}

Significance level: ${ }^{*} 1 \%,{ }^{* \star} 5 \%,{ }^{* \star *} 10 \%$

\begin{tabular}{|c|c|c|c|c|c|c|c|c|c|c|}
\hline \multirow{2}{*}{$\begin{array}{c}\text { Post } 2001 \\
2001-2007 \\
\text { Total Income }\end{array}$} & \multicolumn{2}{|c|}{$\begin{array}{c}\text { Total } \\
\text { Income }\end{array}$} & \multicolumn{2}{|c|}{$\begin{array}{l}\text { Wage } \\
\text { Income }\end{array}$} & \multicolumn{2}{|c|}{$\begin{array}{c}\text { Other } \\
\text { Sources of } \\
\text { Income } \\
\end{array}$} & \multicolumn{2}{|c|}{$\begin{array}{l}\text { UK House } \\
\text { Index }\end{array}$} & \multicolumn{2}{|c|}{ FTSE100 } \\
\hline & 1.000 & & 0.716 & * & 0.930 & * & -0.331 & $* * *$ & 0.341 & *** \\
\hline $\begin{array}{l}\text { Wage Income } \\
\text { Other Sources of }\end{array}$ & 0.716 & * & 1.000 & & 0.410 & $* *$ & -0.154 & & -0.060 & \\
\hline Income & 0.930 & * & 0.410 & ** & 1.000 & & -0.348 & $* * *$ & 0.480 & ** \\
\hline UK House Index & -0.331 & $\star * *$ & -0.154 & & -0.348 & $* * *$ & 1.000 & & -0.676 & * \\
\hline FTSE100 & 0.341 & $\star * *$ & -0.060 & & 0.480 & $\star *$ & -0.676 & * & 1.000 & \\
\hline
\end{tabular}

Significance level: * $1 \%,{ }^{* *} 5 \%$, ${ }^{* *} 10 \%$ 
Table 5. OLS Regression: Determinants of the Number of Instruments (ex-XXXX Pension Scheme) (Standard Error in Parenthesis)

\begin{tabular}{|c|c|c|c|c|c|}
\hline & \multicolumn{2}{|l|}{ OLS } & & \multicolumn{2}{|l|}{ OLS } \\
\hline \multicolumn{3}{|l|}{ Age (Baseline: Under 29) } & \multirow{2}{*}{\multicolumn{3}{|c|}{$\begin{array}{l}\text { I am relying on someone else to } \\
\text { support me in my retirement }{ }^{/ a}\end{array}$}} \\
\hline \multirow[t]{2}{*}{$30-39$} & 0.181436 & $* * *$ & & & \\
\hline & $(0.098)$ & & Strongly Disagree & 0.375336 & * \\
\hline \multirow[t]{2}{*}{$40-49$} & 0.615557 & * & & $(0.126)$ & \\
\hline & $(0.117)$ & & Disagree & 0.230625 & *** \\
\hline \multirow[t]{2}{*}{$50-59$} & 0.738358 & * & & $(0.126)$ & \\
\hline & $(0.179)$ & & Agree & 0.548663 & ** \\
\hline \multirow[t]{2}{*}{$60-65$} & 0.336071 & & & $(0.268)$ & \\
\hline & $(0.308)$ & & Strongly Agree & 1.519496 & ** \\
\hline \multirow[t]{2}{*}{ Over 65} & 0.001571 & & & $(0.588)$ & \\
\hline & $\begin{array}{l}(0.489) \\
0.19593\end{array}$ & * & \multicolumn{3}{|c|}{$\begin{array}{l}\text { The house that I live will provide the } \\
\text { majority of my retirement needs }\end{array}$} \\
\hline Spouse Pension (Yes=1) & $(0.069)$ & & \multirow[t]{2}{*}{ Strongly Disagree } & 0.213188 & \\
\hline \multirow[t]{2}{*}{ Gender (Female=1) } & 0.132334 & & & (0.292) & \\
\hline & $(0.083)$ & & Disagree & -0.06849 & \\
\hline \multicolumn{3}{|l|}{ Status (Baseline: Single) } & & $(0.121)$ & \\
\hline Married & $\begin{array}{c}-0.13644 \\
(0.186)\end{array}$ & & Agree & $\begin{array}{c}-0.02674 \\
(0.082)\end{array}$ & \\
\hline Separated & $\begin{array}{c}0.066635 \\
(0.902)\end{array}$ & & Strongly Agree & $\begin{array}{c}-0.13225 \\
(0.106)\end{array}$ & \\
\hline \multicolumn{3}{|c|}{ Job (Baseline: Executive Director) } & \multirow{2}{*}{\multicolumn{3}{|c|}{$\begin{array}{l}\text { I would like to do more to plan for my } \\
\text { retirement, but don't know }\end{array}$}} \\
\hline \multirow[t]{2}{*}{ Non-Officer } & -0.76255 & * & & & \\
\hline & $(0.148)$ & & Strongly Disagree & -0.02082 & \\
\hline \multirow[t]{2}{*}{ Associate Director } & -0.67909 & * & & $(0.138)$ & \\
\hline & $(0.136)$ & & Disagree & -0.10559 & \\
\hline \multirow[t]{2}{*}{ Director } & -0.35006 & * & & $(0.090)$ & \\
\hline & $(0.131)$ & & Agree & 0.070815 & \\
\hline \multirow[t]{2}{*}{ Managing Director } & 0.199429 & & & $(0.091)$ & \\
\hline & $(0.184)$ & & Strongly Agree & -0.0481 & \\
\hline \multicolumn{3}{|c|}{ Income (Baseline: Low Income) } & & $(0.176)$ & \\
\hline Medium Income & $\begin{array}{c}-0.33792 \\
(0.172)\end{array}$ & 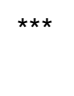 & \multicolumn{3}{|c|}{$\begin{array}{l}\text { I would like to do more to plan for my } \\
\text { retirement, but cannot afford }\end{array}$} \\
\hline High Income & $\begin{array}{c}-0.09808 \\
(0.130)\end{array}$ & & Strongly Disagree & $\begin{array}{c}0.082946 \\
(0.220)\end{array}$ & \\
\hline Planning for my retireme & $t$ is importa & int $^{/ a}$ & Disagree & 0.024484 & \\
\hline Strongly Disagree & 0.633619 & & & $(0.140)$ & \\
\hline & $(0.608)$ & & Agree & -0.0777 & \\
\hline Disagree & 0.124707 & & & $(0.075)$ & \\
\hline & $(0.234)$ & & Strongly Agree & -0.01988 & \\
\hline Agree & $\begin{array}{c}0.207935 \\
(0.143)\end{array}$ & & & (0.189) & \\
\hline Strongly Agree & 0.240021 & & $\begin{array}{l}\text { Risk Tolerant } \\
\text { (Yes=1) }\end{array}$ & 0.285335 & * \\
\hline & $(0.147)$ & & & $(0.072)$ & \\
\hline $\begin{array}{l}\text { I am confident that I am d } \\
\text { for my retirement }\end{array}$ & ing enoug & & Constant & 2.1582 & * \\
\hline Strongly Disagree & $\begin{array}{c}-0.73092 \\
(0.285)\end{array}$ & $* *$ & & $(0.300)$ & \\
\hline Disagree & $\begin{array}{c}-0.18297 \\
(0.096)\end{array}$ & $* \star \star$ & & & \\
\hline Agree & 0.248899 & * & & & \\
\hline & $(0.086)$ & & $\mathrm{F}_{(40,1373)}$ & 10.03 & \\
\hline Strongly Agree & 0.421969 & * & $R^{2}$ & 0.2249 & \\
\hline & $(0.151)$ & & $\mathrm{N}$ & 1424 & \\
\hline
\end{tabular}

Significance level: ${ }^{\star} 1 \%,{ }^{* *} 5 \%,{ }^{\star * *} 10 \%{ }^{\text {la }}$ Baseline: Neither Agree nor Disagree 
Table 6. Property as a Retirement Savings Instrument (ex-XXXX Pension Scheme)

\begin{tabular}{crr}
\hline \hline & Observations & $\begin{array}{c}\text { As fraction of } \\
\text { the sample }\end{array}$ \\
\hline \hline $\begin{array}{l}\text { Only property or property and any other } \\
\text { instrument }\end{array}$ & 624 & $26.3 \%$ \\
\hline G1 Property & 65 & $2.7 \%$ \\
G2 Property + 1 other asset & 138 & $5.8 \%$ \\
G3 Property + 2 other assets & 187 & $7.9 \%$ \\
G4 Property + 3 other assets & 133 & $5.6 \%$ \\
G5 Property + 4 other assets & 68 & $2.9 \%$ \\
G6 Property +5 or more other assets & 33 & $1.4 \%$ \\
Any number of non-property instruments & 1,412 & $59.5 \%$ \\
\hline & & \\
No other instruments & 336 & $14.2 \%$ \\
\hline Total & 2,372 & $100.0 \%$ \\
\hline \hline
\end{tabular}


Table 7. Probit Regression. Probability of Property Included in Respondents' Retirement Portfolios (Marginal Probabilities, $Z$ values in Parenthesis)

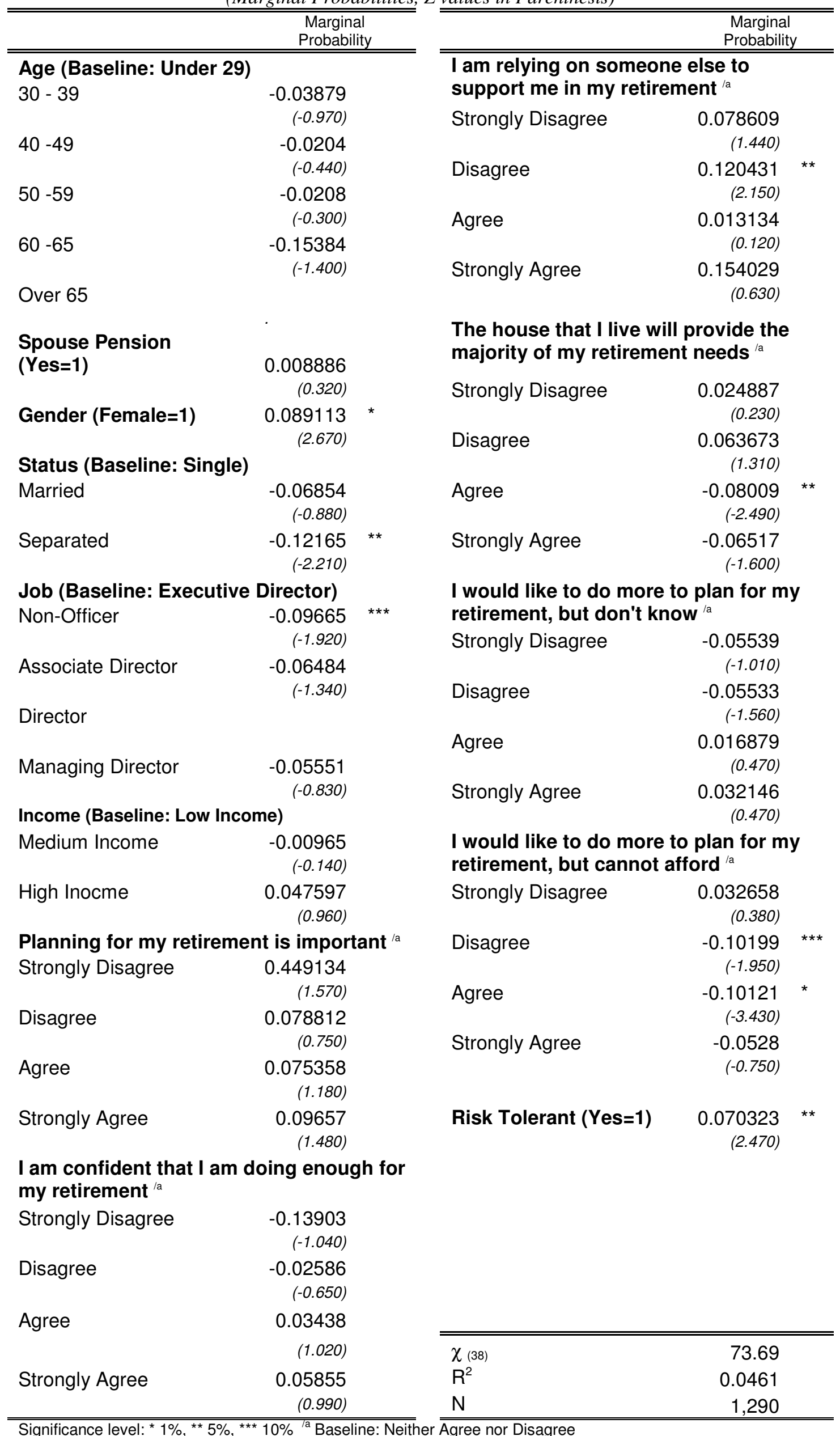


Table 8. OL Regression. Determinants of being in One of Five Groups of Respondents that Rely on Property and Other Instrument(s) (ex-XXXX Pension Scheme) (Standard Error in Parenthesis)

\begin{tabular}{|c|c|c|c|c|c|}
\hline & \multicolumn{2}{|c|}{ Order Logit } & & \multicolumn{2}{|c|}{ Order Logit } \\
\hline \multicolumn{3}{|c|}{ Age (Baseline: Under 29) } & \multirow{2}{*}{\multicolumn{3}{|c|}{$\begin{array}{l}\text { I am relying on someone else to support } \\
\text { me in my retirement }{ }^{/ a}\end{array}$}} \\
\hline \multirow[t]{2}{*}{$30-39$} & \multirow{2}{*}{\multicolumn{2}{|c|}{$\begin{array}{r}0.136033 \\
(0.268)\end{array}$}} & & & \\
\hline & & & \multirow[t]{2}{*}{ Strongly Disagree } & \multicolumn{2}{|l|}{0.694789} \\
\hline \multirow[t]{2}{*}{$40-49$} & 0.71161 & ** & & $(0.431)$ & \\
\hline & $(0.327)$ & & \multirow[t]{2}{*}{ Disagree } & 0.453664 & \\
\hline \multirow[t]{2}{*}{$50-59$} & 1.071705 & ** & & $(0.435)$ & \\
\hline & $(0.517)$ & & \multirow[t]{2}{*}{ Agree } & 1.333497 & \\
\hline \multirow[t]{2}{*}{$60-65$} & \multicolumn{2}{|l|}{0.180972} & & $(0.824)$ & \\
\hline & \multicolumn{2}{|l|}{ n.a, } & Strongly Agree & $\begin{array}{r}3.07767 \\
(1.606)\end{array}$ & $* * * *$ \\
\hline \multirow[t]{2}{*}{$\begin{array}{l}\text { (dropped due to collinearit) } \\
\text { Spouse Pension } \\
\text { (Yes=1) }\end{array}$} & \multirow{2}{*}{\multicolumn{2}{|c|}{$\begin{array}{r}0.11993 \\
(0.198)\end{array}$}} & \multicolumn{3}{|c|}{$\begin{array}{l}\text { The house that I live will provide the } \\
\text { majority of my retirement needs }\end{array}$} \\
\hline & & & Strongly Disagree & $\begin{array}{r}-0.40912 \\
(0.745)\end{array}$ & \\
\hline Gender (Female=1) & Status (Baseline: Single) & & Disagree & $\begin{array}{r}-0.2888 \\
(0.311)\end{array}$ & \\
\hline Married & \multicolumn{2}{|l|}{$\begin{array}{r}0.665701 \\
(0.525)\end{array}$} & Agree & $\begin{array}{r}-0.22746 \\
(0.236)\end{array}$ & \\
\hline Separated & \multicolumn{2}{|l|}{$\begin{array}{r}0.410657 \\
(1.241)\end{array}$} & Strongly Agree & $\begin{array}{r}-0.0824 \\
(0.303)\end{array}$ & \\
\hline \multicolumn{3}{|c|}{ Job (Baseline: Executive Director) } & \multirow{2}{*}{\multicolumn{3}{|c|}{$\begin{array}{l}\text { I would like to do more to plan for my } \\
\text { retirement, but don't know }\end{array}$}} \\
\hline Non-Officer & -0.60095 & & & & \\
\hline & (0.393) & & Strongly Disagree & 0.18405 & \\
\hline Associate Director & -0.52878 & & & $(0.438)$ & \\
\hline & $(0.357)$ & & Disagree & -0.14039 & \\
\hline Director & -0.36113 & & & (0.263) & \\
\hline & (0.336) & & Agree & 0.276997 & \\
\hline Managing Director & 0.388336 & & & $(0.250)$ & \\
\hline Income (Baseline: Low & $\mathrm{me})^{(0.488)}$ & & Strongly Agree & $\begin{array}{r}-0.07087 \\
(0.454)\end{array}$ & \\
\hline Medium Income & $\begin{array}{r}-1.41488 \\
(0.508)\end{array}$ & * & $\begin{array}{l}\text { I would like to do more } \\
\text { retirement, but cannot }\end{array}$ & $\begin{array}{l}\text { plan for my } \\
\text { ord }^{/ a}\end{array}$ & \\
\hline High Income & $\begin{array}{r}-0.73485 \\
(0.356)\end{array}$ & ** & Strongly Disagree & $\begin{array}{r}-0.15908 \\
(0.528)\end{array}$ & \\
\hline Planning for my reti & nt is import & ant $^{/ a}$ & Disagree & -0.06585 & \\
\hline Strongly Disagree & 0.569115 & & & $(0.422)$ & \\
\hline & $(1.323)$ & & Agree & 0.017296 & \\
\hline Disagree & 0.895199 & & & $(0.209)$ & \\
\hline & $(0.740)$ & & Strongly Agree & -0.27492 & \\
\hline Agree & $\begin{array}{r}0.980136 \\
(0.476)\end{array}$ & ** & Risk Tolerant (Yes=1) & $\begin{array}{r}(0.550) \\
0.6711\end{array}$ & * \\
\hline Strongly Agree & $\begin{array}{r}0.732383 \\
(0.486)\end{array}$ & & & (0.198) & \\
\hline $\begin{array}{l}\text { I am confident that I } \\
\text { for my retirement }{ }^{/ a}\end{array}$ & oing enoug & & & & \\
\hline Strongly Disagree & $\begin{array}{r}0.221922 \\
(1.180)\end{array}$ & & & & \\
\hline Disagree & $\begin{array}{r}0.077274 \\
(0.307)\end{array}$ & & & & \\
\hline Agree & 0.297399 & & & & \\
\hline & $(0.241)$ & & $\chi^{22(39)}$ & 110.75 & * \\
\hline Strongly Agree & $\begin{array}{r}0.722334 \\
(0.382)\end{array}$ & $* * * *$ & $\begin{array}{l}\text { pseudo } R^{2} \\
N\end{array}$ & $\begin{array}{r}0.0817 \\
403\end{array}$ & \\
\hline
\end{tabular}

Significance level: ${ }^{\star} 1 \%,{ }^{* *} 5 \%,{ }^{* * *} 10 \%{ }^{1 a}$ Baseline: Neither Agree nor Disagree 
Table 9. Estimated Probability of Belonging to any of the Five Groups of Respondents that rely on Property and another Instrument(s) (ex-XXXX Pension Scheme)

\begin{tabular}{|c|c|c|c|c|c|c|}
\hline & Property & $\begin{array}{l}\text { Property }+1 \\
\text { instrument }\end{array}$ & $\begin{array}{l}\text { Property }+2 \\
\text { instruments }\end{array}$ & $\begin{array}{l}\text { Property }+3 \\
\text { instruments }\end{array}$ & $\begin{array}{l}\text { Property }+4 \\
\text { instruments }\end{array}$ & $\begin{array}{c}\text { Property }+5 \\
\text { or more } \\
\text { instruments }\end{array}$ \\
\hline \multicolumn{7}{|l|}{ Age } \\
\hline Under $29^{\prime a}$ & 22.34 & 27.68 & 27.10 & 15.28 & 5.47 & 2.14 \\
\hline $30-39$ & 14.50 & 23.03 & 28.67 & 20.57 & 9.08 & 4.13 \\
\hline $40-49$ ** & 7.84 & 15.52 & 25.91 & 26.11 & 15.60 & 9.02 \\
\hline $50-59$ ** & 6.56 & 13.79 & 24.85 & 26.67 & 17.07 & 11.06 \\
\hline $60-65$ & 14.36 & 24.60 & 30.72 & 19.88 & 7.48 & 2.96 \\
\hline Over 65 & 25.58 & 24.26 & 24.04 & 15.82 & 7.07 & 3.22 \\
\hline \multicolumn{7}{|l|}{ Spouse Pension } \\
\hline Yes & 13.40 & 21.47 & 27.83 & 21.51 & 10.46 & 5.34 \\
\hline $\mathrm{No}^{/ \mathrm{a}}$ & 14.97 & 22.13 & 27.26 & 20.64 & 10.00 & 5.00 \\
\hline \multicolumn{7}{|l|}{ Gender } \\
\hline Female & 11.53 & 19.85 & 27.79 & 23.02 & 11.73 & 6.07 \\
\hline Male $^{/ a}$ & 20.30 & 26.37 & 27.07 & 16.53 & 6.66 & 3.06 \\
\hline \multicolumn{7}{|l|}{ Status } \\
\hline Married & 13.48 & 21.43 & 27.72 & 21.52 & 10.51 & 5.34 \\
\hline Single $^{/ a}$ & 29.64 & 30.04 & 23.97 & 11.26 & 3.68 & 1.40 \\
\hline $\begin{array}{l}\text { Separated } \\
\text { Job }\end{array}$ & 33.07 & 33.86 & 21.95 & 8.08 & 2.25 & 0.79 \\
\hline Non-Officer & 22.94 & 28.17 & 26.84 & 14.69 & 5.23 & 2.14 \\
\hline Associate Director & 14.26 & 24.00 & 30.15 & 20.35 & 7.99 & 3.25 \\
\hline Director & 10.16 & 19.55 & 29.59 & 24.46 & 11.25 & 4.98 \\
\hline Executive Director ${ }^{\prime a}$ & 4.76 & 11.22 & 23.48 & 29.19 & 19.58 & 11.77 \\
\hline $\begin{array}{l}\text { Managing Director } \\
\text { Income }\end{array}$ & 2.20 & 5.93 & 15.98 & 28.44 & 26.87 & 20.58 \\
\hline Low Income ${ }^{\prime a}$ & 3.27 & 8.27 & 19.71 & 29.29 & 23.39 & 16.06 \\
\hline Medium * & 29.26 & 30.88 & 24.27 & 10.96 & 3.39 & 1.24 \\
\hline High Income ** & 12.92 & 22.48 & 29.94 & 21.73 & 9.09 & 3.84 \\
\hline \multicolumn{7}{|c|}{ Planning for my retirement is important } \\
\hline Strongly Disagree & 11.03 & 20.31 & 26.53 & 19.04 & 11.81 & 11.28 \\
\hline $\begin{array}{l}\text { Disagree } \\
\text { Neither Agree nor }\end{array}$ & 18.57 & 25.70 & 27.71 & 17.73 & 7.22 & 3.07 \\
\hline $\begin{array}{l}\text { Neither Agree nor } \\
\text { Disagree }\end{array}$ & 32.02 & 29.75 & 22.29 & 10.62 & 3.78 & 1.55 \\
\hline Agree ** & 13.41 & 22.18 & 28.63 & 21.36 & 9.78 & 4.65 \\
\hline Strongly Agree & 11.97 & 19.91 & 27.23 & 22.63 & 11.88 & 6.39 \\
\hline \multicolumn{7}{|c|}{ I am confident that I am doing enough for my retirement } \\
\hline Strongly Disagree & 18.22 & 25.22 & 28.80 & 18.27 & 6.81 & 2.67 \\
\hline Disagree & 18.70 & 25.28 & 27.47 & 17.77 & 7.36 & 3.42 \\
\hline Neither Agree nor & & & & & & \\
\hline Disagree $^{/ a}$ & 17.11 & 24.62 & 28.18 & 18.84 & 7.86 & 3.39 \\
\hline Agree & 10.52 & 19.03 & 27.77 & 23.84 & 12.42 & 6.42 \\
\hline Strongly Agree ** & 6.60 & 13.78 & 24.34 & 26.31 & 17.49 & 11.49 \\
\hline \multicolumn{7}{|c|}{ I am relying on someone else to support me in my retirement } \\
\hline Strongly Disagree & 10.53 & 18.91 & 27.60 & 23.78 & 12.53 & 6.65 \\
\hline $\begin{array}{l}\text { Disagree } \\
\text { Neither Agree nor }\end{array}$ & 16.46 & 24.43 & 28.32 & 19.14 & 8.09 & 3.56 \\
\hline Disagree $^{/ a}$ & 26.52 & 28.57 & 24.83 & 13.23 & 4.87 & 1.98 \\
\hline Agree & 8.16 & 17.14 & 28.06 & 25.52 & 13.72 & 7.40 \\
\hline Strongly Agree *** & 1.19 & 3.44 & 10.41 & 21.68 & 26.58 & 36.70 \\
\hline
\end{tabular}


Table 9. Continued

\begin{tabular}{|c|c|c|c|c|c|c|}
\hline & Property & $\begin{array}{c}\text { Property }+1 \\
\text { instrument }\end{array}$ & $\begin{array}{l}\text { Property }+2 \\
\text { instruments }\end{array}$ & $\begin{array}{l}\text { Property }+3 \\
\text { instruments }\end{array}$ & $\begin{array}{l}\text { Property }+4 \\
\text { instruments }\end{array}$ & $\begin{array}{c}\text { Property }+5 \\
\text { or more } \\
\text { instruments }\end{array}$ \\
\hline \multicolumn{7}{|c|}{ The house that I live will provide the majority of my retirement needs } \\
\hline Strongly Disagree & 14.22 & 22.75 & 27.93 & 20.04 & 9.47 & 5.58 \\
\hline $\begin{array}{l}\text { Disagree } \\
\text { Neither Agree nor }\end{array}$ & 15.29 & 23.40 & 28.19 & 20.00 & 8.94 & 4.18 \\
\hline Disagree $^{/ a}$ & 13.75 & 21.34 & 27.69 & 21.63 & 10.46 & 5.13 \\
\hline Agree & 14.50 & 22.32 & 27.72 & 20.77 & 9.88 & 4.81 \\
\hline Strongly Agree & 12.89 & 19.99 & 26.72 & 22.00 & 11.66 & 6.74 \\
\hline \multicolumn{7}{|c|}{ I would like to do more to plan for my retirement, but don't know } \\
\hline Strongly Disagree & 16.27 & 24.30 & 28.82 & 19.36 & 7.89 & 3.36 \\
\hline $\begin{array}{l}\text { Disagree } \\
\text { Neither Agree nor }\end{array}$ & 18.92 & 25.74 & 27.24 & 17.29 & 7.34 & 3.48 \\
\hline Disagree $^{/ a}$ & 13.75 & 21.79 & 28.33 & 21.46 & 9.96 & 4.70 \\
\hline Agree & 9.41 & 17.60 & 27.35 & 24.97 & 13.46 & 7.21 \\
\hline Strongly Agree & 8.53 & 15.74 & 24.60 & 24.57 & 16.10 & 10.45 \\
\hline \multicolumn{7}{|c|}{ I would like to do more to plan for my retirement, but cannot afford } \\
\hline Strongly Disagree & 13.15 & 20.89 & 26.92 & 21.10 & 11.34 & 6.60 \\
\hline $\begin{array}{l}\text { Disagree } \\
\text { Neither Agree nor }\end{array}$ & 11.98 & 19.98 & 27.52 & 22.61 & 11.44 & 6.47 \\
\hline Disagree & 15.84 & 23.38 & 27.78 & 19.81 & 8.95 & 4.24 \\
\hline Agree & 13.27 & 20.93 & 27.46 & 21.82 & 10.92 & 5.60 \\
\hline $\begin{array}{l}\text { Strongly Agree } \\
\text { Risk Attitude * }\end{array}$ & 11.60 & 20.07 & 27.71 & 22.65 & 11.82 & 6.15 \\
\hline Risk Tolerant & 8.23 & 16.20 & 26.79 & 25.84 & 14.67 & 8.28 \\
\hline Risk Averse $^{\text {a }}$ & 17.84 & 25.33 & 28.09 & 18.11 & 7.42 & 3.21 \\
\hline
\end{tabular}

Significance level: ${ }^{*} 1 \%,{ }^{* *} 5 \%,{ }^{* \star *} 10 \%$ (Based on the ordered logit regression)

la Baseline 


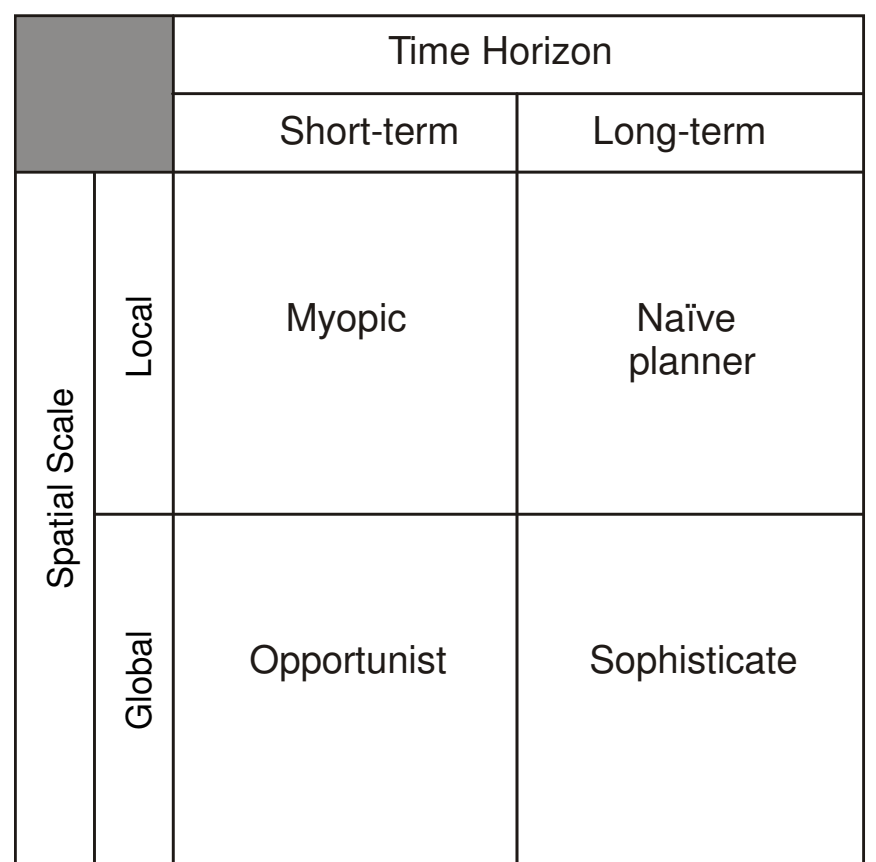

Figure 1. Behavioural predispositions of market agents at the intersection between time and space with respect to financial decision-making under risk and uncertainty 